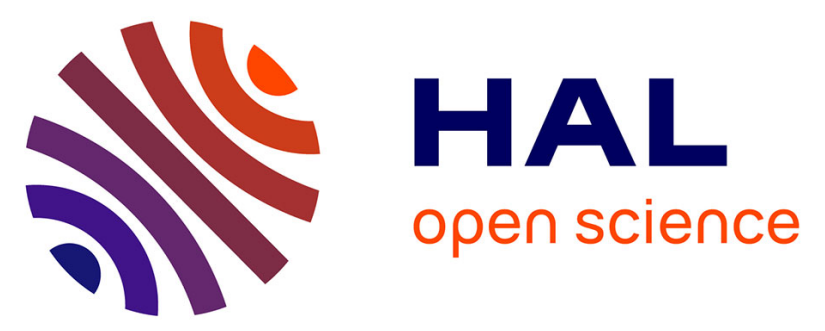

\title{
Combining leeway on farm and supply basin scales to promote technical innovations in lettuce production
}

Mireille Navarrete, Marianne Le Bail, François Papy, Frederique F. Bressoud, Sophie Tordjman

\section{To cite this version:}

Mireille Navarrete, Marianne Le Bail, François Papy, Frederique F. Bressoud, Sophie Tordjman. Combining leeway on farm and supply basin scales to promote technical innovations in lettuce production. Agronomy for Sustainable Development, 2006, 26 (1), pp.77-87. 10.1051/agro:2005062 . hal02659521

\section{HAL Id: hal-02659521 \\ https://hal.inrae.fr/hal-02659521}

Submitted on 30 May 2020

HAL is a multi-disciplinary open access archive for the deposit and dissemination of scientific research documents, whether they are published or not. The documents may come from teaching and research institutions in France or abroad, or from public or private research centers.
L'archive ouverte pluridisciplinaire HAL, est destinée au dépôt et à la diffusion de documents scientifiques de niveau recherche, publiés ou non, émanant des établissements d'enseignement et de recherche français ou étrangers, des laboratoires publics ou privés. 


\title{
Combining leeway on farm and supply basin scales to promote technical innovations in lettuce production
}

\author{
Mireille NAVARRETE* ${ }^{a *}$, Marianne LE BAIL ${ }^{\mathrm{b}}$, François PAPYc ${ }^{\mathrm{c}}$, Frédérique BRESSOUD ${ }^{\mathrm{d}}$, Sophie TORDJMAN \\ a INRA, Unité d'Écodéveloppement, Site AgroParc, 84914 Avignon Cedex 09, France \\ ${ }^{\mathrm{b}}$ INAPG, UMR SADAPT, 16 rue Claude-Bernard, 75231 Paris Cedex 05, France \\ ${ }^{\mathrm{c}}$ INRA, UMR SADAPT, BP 01, 78850 Thiverval-Grignon, France \\ ${ }^{\mathrm{d}}$ INRA, Domaine du Mas Blanc, 66200 Alénya, France
}

(Accepted 9 November 2005)

\begin{abstract}
We analysed the technical and organisational leeway available to market gardeners and marketing firms in the Roussillon region, southeastern France, to meet two qualitative objectives: a longer marketing period and an increasing product safety by replacing soil chemical disinfection with solarisation. We surveyed 33 market gardeners producing lettuce and selling through three different marketing firms. Farmers used two alternative models to stagger harvests and three to introduce solarisation, based on increasing sheltered areas or number of lettuce cycles per year and reducing or abandoning summer crops. The choices of the farmers depended on their own leeway at the farm level or collective leeway at the supply basin level. Leeway at the farm level mainly depended on the area available under shelter and farm labourers' characteristics. The original result is that when no individual leeway is available or when its use affects the basic structure of the farm, marketing firms can enhance the technical innovations by developing closer economical and technical relations with their suppliers, orchestrating improved between-farm coordination and managing the diversity of technical systems and farms at the supply basin level. This study contribute to improving organisational effectiveness, firstly by proposing a method of analysis that is sensitive to the diversity of the resources available and operator strategies. Secondly, it can also be used to identify or predict the emergence of organisational and technical malfunctions. Finally, it broadens the use of farmer decision models, so far mainly developed in major cropping systems, to the case of market garden systems.
\end{abstract}

lettuce / plastic tunnels / solarisation / cropping cycle / decision / marketing firms / market gardening / farm system functioning / crop supply system

\section{INTRODUCTION}

Agricultural production is facing ever increasing demands from the agrifood sector. Downstream operators, particularly supermarkets and superstores, are now seeking to guarantee the quality of a product no longer solely when it is purchased but also during its production. Two quality objectives are targeted in particular for fresh produce: the availability of fresh and ripe produce over the longest possible period and the safety of this produce, that no processing can correct since it is consumed as is. A leafy vegetable such as lettuce that is likely to contain nitrates and residues of chemical products is strictly controlled by national and European regulations (Villeneuve, 1999).

Technical solutions applied at the plot level are used to reach these two objectives. The production period can be prolonged by increasing the number of lettuce cycles per year (Navarrete et al., 2003). Solarisation, i.e. heating up the soil by exposing to sunlight a wet soil covered with plastic mulch for about 2 months, can be used as a chemical-free method to disinfect the soil, thereby reducing the risks associated with chemical residues (Stapleton, 2000). However, the farmers in a major production basin such as the Roussillon area, studied here in 1999 and 2000, have not always adopted these practices. The survey showed that only a third of the farms were producing lettuce for 8 months of the year and $40 \%$ had adopted solarisation.

Our hypothesis is that to meet market requirements, and in particular the need to prolong the production period and enhance product safety, quality management requires changes at levels of organisation other than the plot. The leeway of growers, i.e. their capacity to adopt technical changes at a particular level without endangering farm system functioning at another level, is required at two levels: (1) at the farm level where leeway varies greatly depending on their production, their resources, their objectives and the means employed to reach these objectives (Joannon et al., 2005); and (2) at the level of the organisations responsible for collecting and commercialising the harvest, which are charged with centralising the fragmented offers made by farmers and creating batches that comply with their customers' quality requirements.

Decision-making at the farm level has been the subject of many studies. By using the farmer's cognitive action model (Sebillotte and Soler, 1988) and by evaluating farmers' decisions when facing technical changes (Aubry et al., 1998; Papy, 2001), it is possible to define three levels of decision-making. These involve variables that confer increasing degrees of structure

* Corresponding author: navarret@ avignon.inra.fr 
on farm system functioning. Certain modifications involve only the crop under study and the plot scale, and manifest as changes in crop management sequence, in reasoning or in the application of techniques (level 1). Some more complex innovations in a plot may impact on the area under this crop or even on the areas under other crops and on crop sequence (level 2). Finally, some changes may be far more strategic and affect production resources, their management or the balance between productions (level 3). Before tackling this last level, farmers in their attempts to take account of workload and specification constraints tend to proceed with the most simple adjustments (they make modifications to cultivation techniques, crop sequence and cropping pattern). Besides this technical leeway, farm economical constraints also play a role in adopting technical innovations, but were not taken into account in this study.

The organisation of harvest collection and commercialisation have been analysed in studies that were focused on the quality management of cereal crops (Le Bail, 2004, 2005), processed vegetables (Capillon and Valceschini, 1998) and fresh vegetables (Tordjman et al., 2005). Le Bail (2005) described a local crop supply system on this scale, where the output variable corresponds to a set of product batches qualified with respect to different markets. This system is made up, on the one hand, of plots in the supply basin and their cropping systems, and on the other hand, by the logistic tools used for collection. It is controlled on two levels: (i) the decisions taken by the different operators (different types of farmers and harvest collectors) depending on their own strategies, and (ii) coordination between the various operators which, for any given campaign, brings the different means of coordination into play (contract, workload plans and technical specifications, collection schedules, guidelines and advice). Tordjman et al. (2005) analysed more specifically the job performed by the managers responsible for supplying the firms that market lettuce and described their role as producer coordinators.

By drawing from surveys that concentrated on market gardeners in the Roussillon area and on three marketing firms that purchase their harvest, this paper focuses on the manner in which market gardeners modify crop sequence to meet the two qualitative objectives set by lettuce buyers: a longer marketing period and an increasing product safety. Crop sequence here is taken in its broadest sense, i.e. it includes cropping and intercrop phases. Here we deliberately choose not to consider the crop management sequences used for each crop, although this is also subject to modifications through pressure from the supply chain. This paper therefore shows that these technical changes are very diversely adopted by farms and that this diversity stems from variability in the leeway available to farmers and marketing firms they supply when modifying crop sequence and cropping patterns. It concludes with a discussion of the impact of these results on the design of new cropping systems.

\section{MATERIALS AND METHODS}

\subsection{Global considerations on lettuce production}

The Roussillon (Eastern Pyrenees plain) accounts for more than half the tonnage of lettuce produced in Southeast France, which is the main area of winter lettuce production (70\% of the national production, which reaches 694000 t, Scees 2001). The lettuce is grown either in open fields or under shelter (high plastic tunnels or multispan plastic greenhouses). Although openfield areas have diminished ( $-35 \%$ in 15 years), shelters have progressed sharply (+20\% in 15 years) (Agreste, 2001). Also, the product range has been broadened: conventional lettuce (cos lettuce/romaine, batavia, scarole and frisée) is accompanied by increasingly diversified forms (oak leaf lettuce, and lollos, red and green, Très Fine Maraichère, young lettuce, etc.) varying in leaf colour and shape. Diversification is particularly developed for the ready-to-eat vegetables market which accounts for half the volume. In this production basin, producers and marketing firms have built close relationships between one another from the 1990s, when technical advisors were first hired by private shippers to coordinate lettuce production on a supply basin scale. These two characteristics (large-scale lettuce production and close coordination between production and commercialisation) formed the rationale for conducting the study in the Roussillon region.

The cropping cycle under shelter is about 600 degree days for lettuce and 650 degree days for endive (base $3.5^{\circ} \mathrm{C}$ ), without counting time spent in the nursery. In the Roussillon region, open fields are planted from August to October and the lettuce arrives at maturity 50 to 60 days later when planted in late summer and 100 to 120 later when planted during the winter months (Goisque, 1994). Crops under plastic shelters are planted from September to March and growing cycles are shorter than in open fields (about 40 days in the autumn and 80 days in the winter). In general, this enables 3 lettuce cycles per year. Several species may be cropped after the lettuce under shelter: short cycle so-called "spring" crops harvested until June (courgette and potatoes) and so-called "summer" crops harvested until August or even September (tomato and cucumber). Solarisation is used against soil-borne disease: the soil temperature increases up to $40-50{ }^{\circ} \mathrm{C}$ and this is sufficient to control lettuce pathogens such as Rhizoctonia, Sclerotinia and Olpidium (Katan, 1981). The effectiveness of solarisation depends on duration, soil humidity when the plastic mulch is applied and the rate of the temperature increase (Stapleton, 2000), and this restricts the use of this technique to the hottest months. In the Roussillon region, we retained two major constraints. Firstly, to ensure that soil temperature rises rapidly, the operation must start between mid-June and the end of July, and last at least 45 days for shelters and 60 days for open field (Le Bohec and Giraud, 1999). Secondly, to control pathogen populations effectively, the process must be repeated at least every two years (Anon., 1993).

\subsection{Survey methods}

The management of lettuce-based cropping systems was studied in 33 farms, which were selected to cover a range in products, general functioning and marketing strategies. The survey concerned all the members of co-operative A and half the suppliers of firms B and C. As analysed by a specific survey of the three firms (Tordjman et al., 2005), they are organised differently. Firm A is a co-operative that has chosen to consolidate a highly demanding product, i.e. ready-to-eat vegetables. Contracts with lettuce processing plants specify quantities to be supplied week by week throughout the campaign (strong demand in October-November then in March-May). To comply, the co-operative has drawn up production contracts with its 
Table I. Farm characteristics.

\begin{tabular}{|c|c|c|c|c|c|}
\hline \multirow[b]{2}{*}{ Farm } & \multicolumn{3}{|c|}{ Area } & \multirow[b]{2}{*}{ Crop sequence under shelter* } & \multirow[b]{2}{*}{ Other crops $* *$} \\
\hline & Total & $\begin{array}{l}\text { Lettuce under } \\
\text { shelter }\end{array}$ & $\begin{array}{l}\text { Lettuce in } \\
\text { open field }\end{array}$ & & \\
\hline $\mathrm{A}_{1}$ & 6 & 0.5 & 1.0 & Let-Let-Let & Fruit \\
\hline $\mathrm{A}_{2}$ & 10 & 2.0 & 2.0 & $\begin{array}{l}\text { [Let-Let-Let-sol]-[Let-Let-Let-GM] } \\
\text { Let-Let }\end{array}$ & Fruit \\
\hline $\mathrm{A}_{3}$ & 3.5 & 2.0 & 1.5 & Let-Let-Sum & \\
\hline $\mathrm{A}_{4}$ & 3.5 & 3.5 & & $\begin{array}{l}\text { Let-Let-Let } \\
\text { Let-Let }\end{array}$ & \\
\hline $\mathrm{A}_{5}$ & 3.5 & 0.3 & 0.5 & Let-Let-sol & Fruit \\
\hline $\mathrm{A}_{6}$ & 2 & 0.4 & 0.1 & Let-Let-Sum (evolving into Let-Let-Let) & Fruit \\
\hline $\mathrm{A}_{8}$ & 14 & 1.5 & 11.0 & Let-Let & Fruit \\
\hline $\mathrm{A}_{9}$ & 26 & 0.4 & 10.0 & Let-Let-Sum & Fruit \\
\hline $\mathrm{A}_{10}$ & 9 & 0.5 & 6.0 & Let-Let & \\
\hline $\mathrm{A}_{11}$ & 2 & 2.0 & & Let-Let-Sum & \\
\hline $\mathrm{A}_{12}$ & 25 & 1.5 & 4.0 & Let-Let-Let-sol & Fruit \\
\hline $\mathrm{A}_{13}$ & 16 & 1.0 & 1.0 & Let-Let-Let & Fruit, vine \\
\hline $\mathrm{A}_{14}$ & 6.2 & 1.2 & 5.0 & Let-Let-Sum & \\
\hline $\mathrm{A}_{15}$ & 3 & 1.5 & 0.5 & [Let-Let-sol]-[Let-Let-GM] & Flower, SLT \\
\hline $\mathrm{A}_{16}$ & 8 & 1.2 & 3.0 & Let-Let-Let & SLT, fruit \\
\hline $\mathrm{A}_{17}$ & 8 & 1.0 & 6.0 & [Let-Let-Sum]-[Let-Let-sol] & \\
\hline $\mathrm{B}_{1}$ & 8 & 2.2 & & [Let-Let-sol]-[Let-Let-GM] & Fruit \\
\hline $\mathrm{B}_{2}$ & 52 & 2.0 & 40.0 & Let-Let & \\
\hline $\mathrm{B}_{3}$ & 26 & 0.6 & 1.5 & [Let-Let-sol]-[Let-Let-GM] & Fruit, vine \\
\hline $\mathrm{B}_{4}$ & 13 & 1.5 & 9.5 & $\begin{array}{l}\text { Let-Sum } \\
\text { Let }\end{array}$ & Fruit \\
\hline $\mathrm{B}_{5}$ & 16 & 0.5 & 2.5 & Let-Let-GM & Vine, fruit \\
\hline $\mathrm{B}_{6}$ & 6 & 0.8 & 3.0 & Let-Sum & Fruit \\
\hline $\mathrm{B}_{7}$ & 16 & 1.5 & & [Let-Sum]-[Let-sol] & Fruit \\
\hline $\mathrm{B}_{8}$ & 12 & 0.2 & 7.0 & Let-Spr-GM & Fruit \\
\hline $\mathrm{B}_{9}$ & 4 & 4.0 & & $\begin{array}{l}\text { [Let-Let-Sum }]^{-}[\text {Let-Let-sol] } \\
\text { (evolving into Let-Let-Let-sol) }\end{array}$ & \\
\hline $\mathrm{C}_{1}$ & 4 & 1.0 & 3.0 & $\begin{array}{l}\text { Let-Spr-sol } \\
\text { [Let-Let-sol]-[Let-Let] }\end{array}$ & \\
\hline $\mathrm{C}_{2}$ & 10 & 0.6 & 2.0 & Let-Let-sol & SLT, Vine \\
\hline $\mathrm{C}_{4}$ & 75 & 2.3 & & Let & Fruit \\
\hline $\mathrm{C}_{5}$ & 8 & 0.6 & 0.2 & Let-Sum & Fruit, vine \\
\hline $\mathrm{C}_{6}$ & 7 & 0.7 & 2.0 & Let-Spr-sol & Fruit, vine \\
\hline $\mathrm{C}_{9}$ & 20 & 6.0 & 3.5 & Let-Let-sol & \\
\hline $\mathrm{C}_{13}$ & 10 & 8.0 & & $\begin{array}{l}\text { Let-Let-Sum } \\
\text { Let-Let (evolving into Let-Let-Let) }\end{array}$ & \\
\hline $\mathrm{C}_{14}$ & 10 & 1.0 & 1.0 & Let-Sum & SLT, fruit \\
\hline
\end{tabular}

* Let: lettuce, sol: solarisation, GM: green manure, Sum = summer crop, Spr = spring crop. ** Main crop in bold characters (no indication: lettuce), SLT: soil-less tomato. The crop sequence is indicated over one (e.g. Let-Let) or two years (e.g. [Let-Sum]-[Let-sol]) depending on whether it is repeated every year or every two years. Crop sequences are indicated on two separate lines when different from one shelter to another. In farms $\mathrm{A}_{6}$, $\mathrm{B}_{9}$ and $\mathrm{C}_{13}$, the crop sequence indicated at the date of the survey evolved the year after into another one indicated in brackets.

members. Firms B and $\mathrm{C}$ are private shippers whose emphasis is on bringing fresh product to market. Also, firm B is financially involved in two farms. Firm $\mathrm{C}$ has its own lettuce processing plant that uses less high-quality product that cannot be marketed directly as fresh. $\mathrm{C}$ also controls a farm.

The 33 farms were also characterised by the range of areas devoted to lettuce (up to 40 ha as open fields and 8 ha under shelter) (Tab. I) and can be placed in a global typology of French vegetable-producing farms (Oniflhor et al., 2000) where differentiation is based on the combination of species grown and on the degree of intensification applied to market garden crops (Tab. II). More than half the farms surveyed were highly mixed (Type I). They were growing several market garden species in open fields and under plastic shelters along with 
Table II. Distribution of the farms surveyed.

\begin{tabular}{lccc}
\hline Farm Type & \multicolumn{2}{c}{ Marketing firms } & Total \\
\cline { 2 - 4 } & \multicolumn{1}{c}{$\mathrm{A}$} & $\mathrm{B}$ & $\mathrm{C}$ \\
\hline $\begin{array}{l}\text { Type I } \\
\text { (mixed crops) }\end{array}$ & $\mathrm{A}_{1} \mathrm{~A}_{2} \mathrm{~A}_{5} \mathrm{~A}_{6} \mathrm{~A}_{9} \mathrm{~A}_{12} \mathrm{~A}_{13} \mathrm{~A}_{16}$ & $\mathrm{~B}_{1} \mathrm{~B}_{3} \mathrm{~B}_{5} \mathrm{~B}_{6} \mathrm{~B}_{7} \mathrm{~B}_{8}$ & $\mathrm{C}_{4} \mathrm{C}_{5} \mathrm{C}_{6}$ \\
$\begin{array}{l}\text { Type II } \\
\text { (lettuce-specialised) }\end{array}$ & $\mathrm{A}_{3} \mathrm{~A}_{4} \mathrm{~A}_{8} \mathrm{~A}_{10} \mathrm{~A}_{11} \mathrm{~A}_{14} \mathrm{~A}_{17}$ & $\mathrm{~B}_{2} * \mathrm{~B}_{4} \mathrm{~B}_{9} *$ & $\mathrm{C}_{1} \mathrm{C}_{9} \mathrm{C}_{13} *$ \\
$\begin{array}{l}\text { Type II } \\
\text { (greenhouse-specialised) } \\
\text { Total }\end{array}$ & $\mathrm{A}_{15}$ & & $\mathrm{C}_{2} \mathrm{C}_{14}$ \\
\hline
\end{tabular}

Farms are coded on the basis of the marketing firm which buys their products, followed by a number. The marketing firms are a co-operative (A) and two private shippers (B and C), whose strategy was described in Tordjman et al. (2005). * Farms linked financially to a marketing firm.

fruit trees and vines. The lettuce was generally cropped on less than 5 ha, i.e. less than $40 \%$ of the usable agricultural area. Lettuce-specialised farms (Type II) represented $40 \%$ of the farms surveyed; lettuce area accounted for more than three quarters of usable area, either entirely or partially under shelter, and for more than 5 ha. In Type III farms, the technical competence required by soil-less crops (tomatoes or flowers) made these an economic priority. Lettuce here was generally cropped on less than 5 ha per farm. Such farms were in a minority in the sample and in the population of the production basin.

Each farm survey lasted about 3-5 hours in two visits. It concerned first the analysis of the overall farm system functioning (Capillon, 1993; Landais, 1998) with a diachronic vision to identify past and ongoing changes: family, objectives and history; type and area of cropping systems, cropping plan and technical crop management; production means, including land, equipment, machinery and labour. Then, the survey addressed more specifically the management of lettuce production using the approach used by Maxime et al. (1995) and Aubry et al. (1998) to analyse crop area management. Each plot was characterised: open field or characteristics of shelter, species of lettuce, crop sequences with lettuce, and technical operations involved in the sequence (date, order of operation between plots, working practices, and methods of using inputs, including date, types and amounts). After the identification of management variables and rules for every farm, we drew a graphical representation of the cropping calendar on which the different lettuce crops were positioned along with an indication of plot characteristics, species of lettuce, other crops and technical operations involved in each period. A second visit with every farmer allowed us to refine our initial representation and to discuss their relationship with the marketing firm to understand how these relations affected cropping processes in the different plots (changes in timetable, crop sequence, soil disinfection methods, etc.).

\section{RESULTS AND DISCUSSION}

The survey initially served to identify the different methods used by farms to stagger production cycles and use solarisation (Sect. 3.1). To attain these different combinations, different types of leeway were involved either as far as the organisation of the farm itself was concerned (Sect. 3.2), or the interactions between the farms and marketing firms (Sect. 3.3).

\subsection{Farmers use different technical solutions to stagger production cycles and use solarisation}

We identified, respectively, three and four modalities for each technique: the harvest is staggered over three (model $\mathrm{H} 0$ in Fig. 1), five (model H1) and eight months (model H2); sometimes without solarisation (S0), or with three alternative methods to use solarisation (S1 to $\mathrm{S} 3$ ).

\subsubsection{From HO to H2: larger number of cycles per plot and a combination of open field and shelter to stagger the harvest}

The lettuce production period for the crop sequence given in Figure 1a is at most 3 months (H0): the open field produces in October and two tunnels with one cycle are sufficient to ensure production in December and January. For any given area of lettuce production, farmers may use two levers to extend the harvest over a longer and continuous period (Fig. 2): (1) lettuce is planted over a longer period (which can mean staggering plantings by a few weeks within a cycle or alternatively increasing the number of cycles per plot); (2) several shelters and openfield crops are combined.

Two crop sequence models can therefore be distinguished depending on the degree of intensification (Tab. III): in model $\mathrm{H} 1$ the production period is longer than that in $\mathrm{H} 0$ (extended from 3 to 5 months) but the plants are harvested once or twice weekly. Market gardeners combine both one-cycle and twocycle lettuce tunnels. In model $\mathrm{H} 2$ lettuce is produced over 8 months and is harvested regularly (several times a week or even every day) thanks to a combination of open-field plots and 2or 3-cycle lettuce tunnels.

In this manner in $\mathrm{H} 2$ (Fig. 2) the first cycle under shelter, planted in early September, is harvested the last fortnight of October; the second, planted in early November, is harvested in mid-January and the third, planted in early February, is harvested in mid-April. The interval between two successive crops is therefore very short (at most one week). At the same time, the 2-cycle tunnels bolster production in November-December and in March-April. The open-field crop is planted very early for production in October, thereby avoiding competition with the 


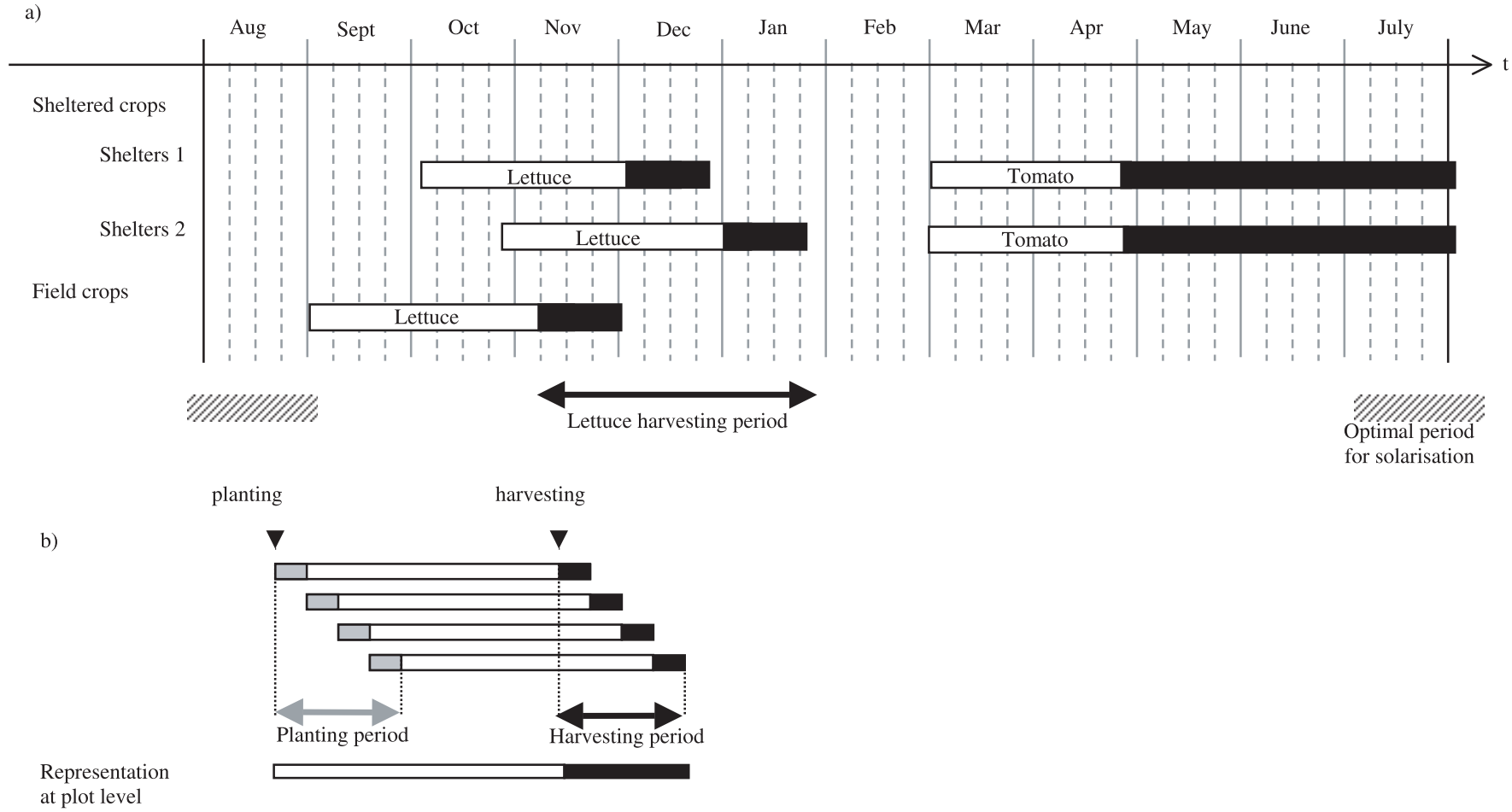

Figure 1. Organisation of crop sequences including lettuce crops. An example in Roussillon (model H0). (a) Global organisation at the farm level. White segment indicates the cropping cycle, from planting to the beginning of harvesting. Black segment indicates the harvesting period. Striped segment indicates the optimal period for solarisation. (b) Real organisation at the plot level and simplified representation of a lettuce plot. In this example, the plot is divided into 4 parts, corresponding to the area that can be planted by staff during one week. Thus, plot production lasts 4 to 6 weeks. As a simplification, only the plot level is represented in Figures 1-3, therefore with a harvesting period that lasts several weeks.

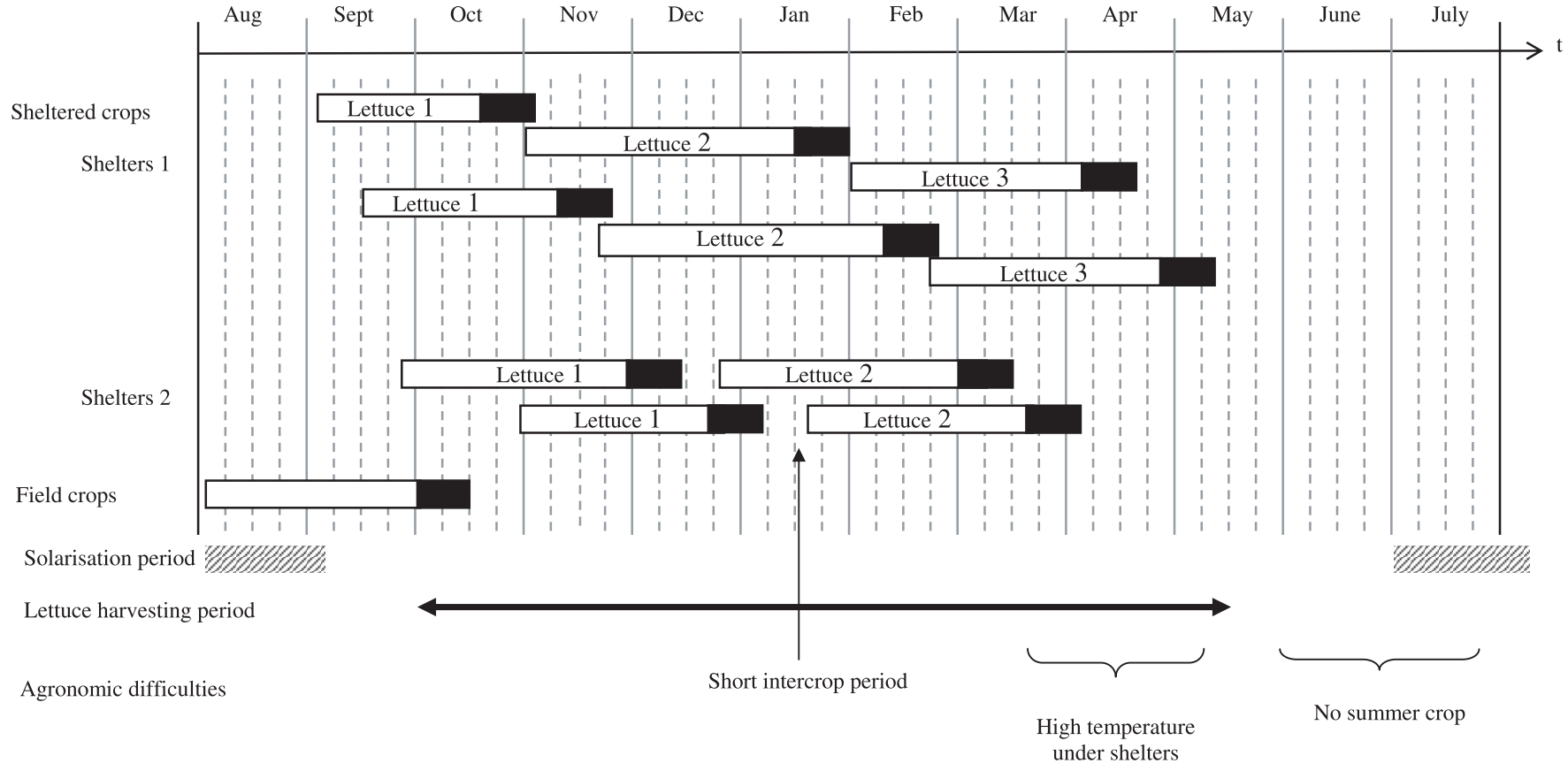

Figure 2. Combination of several crop sequences to stagger the lettuce harvesting period (model H2). The shelters are divided into two groups, the first one with three lettuce cropping cycles, and the second one with two. White segment: cropping cycle from planting to the beginning of harvesting. Black segment: harvesting period. Striped segment: optimal period for solarisation. 


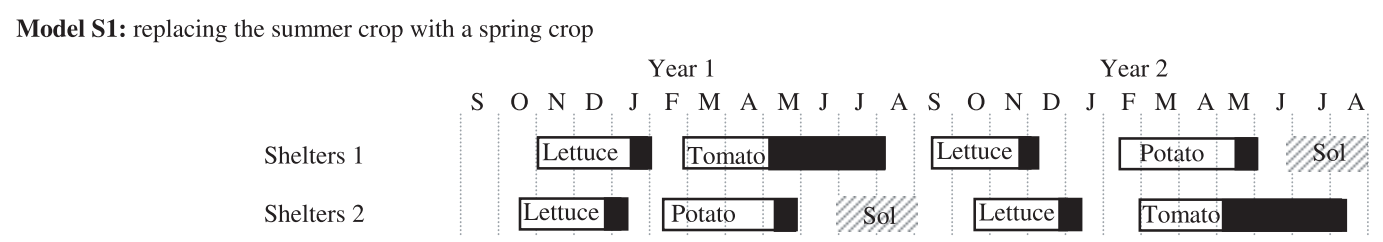

Model S2: dividing the summer crop area in half

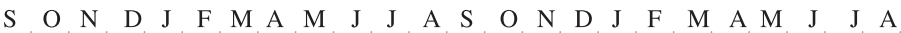

Shelters 1

Shelters 2
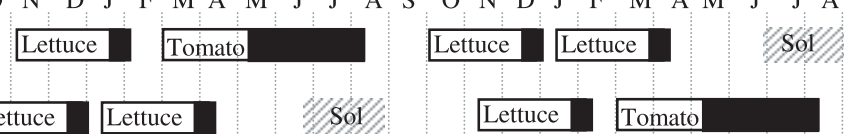

Model S3: Stopping the summer crop

Shelters $1+2$

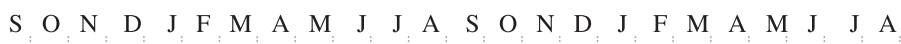

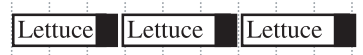

$\bigotimes_{\mathcal{O}}$ Lettuce Lettuce Lettuce

Q 6

Figure 3. Three crop sequence models to introduce solarisation under plastic shelter. White segment: cropping cycle from planting to the beginning of harvesting. Black segment: harvesting period on plot scale. Striped segment: solarisation period.

Table III. Three models for staggering lettuce harvesting dates.

\begin{tabular}{|c|c|c|c|}
\hline \multirow[t]{2}{*}{ Harvesting period } & \multicolumn{3}{|c|}{ Harvesting frequency } \\
\hline & Once a week or less & Several times a week & Every day \\
\hline \multicolumn{4}{|c|}{ H0 (3 farms) } \\
\hline \multirow[t]{2}{*}{3 months } & & $\begin{array}{l}\text { I: } B_{6} C_{4} \\
\text { III: } C_{14}\end{array}$ & I: $B_{7}$ \\
\hline & & & \\
\hline \multirow[t]{2}{*}{5 months } & $\begin{array}{c}\text { I: } A_{5} A_{6} B_{3} B_{5} C_{5} C_{6} \\
\text { II: } A_{10} \\
\text { III: } A_{15} C_{2}\end{array}$ & $\begin{array}{c}\text { I: } B_{1} B_{8} \\
\text { II: } A_{3} A_{8} A_{11} A_{14} A_{17} B_{4} C_{1}\end{array}$ & \\
\hline & & \multicolumn{2}{|c|}{ H2 (10 farms) } \\
\hline 8 months & I: $A_{1}$ & $\begin{array}{c}\text { I: } \mathrm{A}_{9} \mathrm{~A}_{12} \mathrm{~A}_{13} \mathrm{~A}_{16} \\
\text { II: } \mathrm{B}_{2}\end{array}$ & $\begin{array}{c}\text { I: } A_{2} \\
\text { II: } A_{4} B_{9} C_{9} C_{13}\end{array}$ \\
\hline Shelters mean area (ha) & 0.67 & 1.3 & 4.2 \\
\hline Standard deviation & 0.35 & 0.68 & 2.5 \\
\hline
\end{tabular}

Cells regrouping most of the farms are shaded.

harvest from the first cycle in the tunnels. This combination of crop sequences results in regular production and spreads the workload but it requires rigorous organisation to avoid the cycles overlapping. Although tomato can be cropped under the same tunnels as the lettuce in model $\mathrm{H} 1$, this is impossible in model $\mathrm{H} 2$ because of the 3 lettuce cycles. In actual fact, only 3 farms were employing model $\mathrm{H} 0$ and producing over 3 months. The intermediate model $\mathrm{H} 1$ was used by 18 farms and 10 employed model $\mathrm{H} 2$, the most intensive, with 5 of these farms producing daily for 8 months.

\subsubsection{From SO to S3: reduced summer cropping area for the introduction of solarisation}

Crop sequences conducted under shelter and including a summer crop (Fig. 1) are incompatible with solarisation in July/ August (S0). By contrast, farmers are able to use solarisation in three other crop sequence models (Fig. 3).

Model S1: The summer crop is replaced by a spring crop on half the area. A shorter duration spring crop (e.g. early potatoes or courgettes harvested in mid-May) can be used in each 
Table IV. Combining the two marketing firms' requirements: introducing solarisation and staggering harvesting dates.

\begin{tabular}{|c|c|c|c|c|}
\hline & $\begin{array}{c}\mathrm{H} 0 \\
\begin{array}{c}\text { Discontinuous harvest over } \\
\text { three months }\end{array}\end{array}$ & $\begin{array}{c}\text { H1 } \\
\begin{array}{c}\text { Discontinuous harvest over five } \\
\text { months }\end{array}\end{array}$ & $\begin{array}{c}\mathrm{H} 2 \\
\text { Continuous harvest over eight } \\
\text { months }\end{array}$ & Total \\
\hline $\begin{array}{l}\text { S0 } \\
\text { No solarisation: summer crops } \\
\text { under every shelter }\end{array}$ & $\begin{array}{c}\mathrm{B}_{6} \\
\mathrm{C}_{14}\end{array}$ & $\begin{array}{llll}\mathrm{A}_{3} & \mathrm{~A}_{6} & \mathrm{~A}_{11} & \mathrm{~A}_{14}\end{array}$ & $\mathrm{~A}_{9}$ & 7 \\
\hline $\begin{array}{l}\text { S1 } \\
\text { Summer crop } \\
\text { under part of the shelters }\end{array}$ & & $\mathrm{B}_{4} \mathrm{C}_{5}$ & $\underline{\mathrm{C}}_{2}$ & 3 \\
\hline $\begin{array}{l}\text { S2 } \\
\text { Summer crop } \\
\text { every two years }\end{array}$ & $\underline{\mathrm{B}}_{7}$ & $\underline{\mathrm{A}}_{17}$ & $\underline{\mathrm{B}}_{9}$ & 3 \\
\hline $\begin{array}{l}\text { S3 } \\
\text { No summer crop }\end{array}$ & $\mathrm{C}_{4}$ & $\begin{array}{llllll}\underline{\mathrm{A}}_{5} & \mathrm{~A}_{8} & \mathrm{~A}_{10} & \mathrm{~A}_{15} & \mathrm{~B}_{1} \\
\underline{\mathrm{B}}_{3} & \mathrm{~B}_{5} & \mathrm{~B}_{8} & \underline{\mathrm{C}}_{1} & \underline{\mathrm{C}}_{2} & \underline{\mathrm{C}}_{6}\end{array}$ & 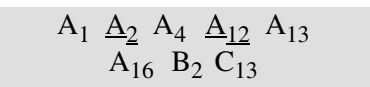 & 20 \\
\hline Total number of farms & 4 & 18 & 11 & \\
\hline
\end{tabular}

Farms using the solarisation technique are underlined. Cells regrouping most of the farms are shaded.

plot to combine a lettuce crop in winter, a spring crop and solarisation. By alternating sequences between two groups of tunnels, tomato can be grown every year but on half the area.

Model S2: Removal of the summer crop from half the area and intensification for lettuce. In the same manner as for the previous case a single crop sequence covers a period of two years: lettuce then solarisation in year $n$ followed by lettuce then a summer crop in year $n+1$. Here again the summer crop area is reduced by half. In the years where no summer crop is grown, the tunnels can be used to increase the number of lettuce cycles ( 2 or even 3 ) prior to solarisation compared with only one in model S0.

Model S3: Total discontinuation of summer crops and switch to lettuce monocrop with varying degrees of intensification. The summer crop is removed entirely under the shelters. This makes it possible to intensify lettuce cropping by using 2 or 3 successive cycles in the winter. Solarisation can therefore take place every year, or in alternate years with green manure. This aims to maintain the soil in a satisfactory structural and biological condition to counteract the possible degradation caused by lettuce monocropping. In the sample evaluated, the S3 model was most common (20 farms, with 10 using solarisation) whereas only 3 farms each used models S1 and S2 (Tab. IV).

\subsubsection{Various consequences of adopting the two technical innovations}

Thus, it is shown that a large proportion of the farms surveyed have the capacity to stagger harvests and introduce solarisation, but their technical solutions raise several agronomic questions. The problem facing mixed farms that choose to maintain summer crops is disease control by other than chemical means because they are unable to practice solarisation under optimal conditions, i.e. every other year for 45 days in the summer (Le Bohec and Giraud, 1999). Few agronomic studies have so far examined the use of this technique under other than optimal conditions while taking account of the management constraints facing market gardeners. Three alterna- tives to this model could be evaluated. The first would consist of reducing solarisation frequency from 1 year out of 2 to 1 year out of 3. In this manner, summer crops would be less penalised. The second method would be to shorten the solarisation period and shift it to August-September. This would allow summer cropping to continue and is already being tried by some farmers. A combination of this method with lower dose chemical disinfection has already been evaluated (Minuto et al., 2000). Although it does not necessarily resolve the constraints imposed by marketing firms, it does limit the damage caused to the environment and lowers the risk of toxic residues being found in the lettuce. Third, if chemical disinfection is to be definitively avoided, other solutions must be found that combine solarisation under suboptimal conditions and alternative cropping techniques such as the use of organic amendments (Nico et al., 2003), biocontrol agents (Jones et al., 2004), resistant or less susceptible varieties (Latham and Jones, 2004), or rotation effects (Hao et al., 2003). With this approach, openfield cropping, which up to now has been minimised, could become of strategic importance by reducing the health and safety pressure exerted on crops under shelter. The interest of such already identified solutions in local conditions could be evaluated in experimental designs. New leeway on the farm scale may be identified using the ROTAT model (Dogliotti et al., 2004), based on generation and evaluation of every possible crop sequence, assuming that this model can easily be adapted to infra-annual crops.

Farms that intensify their lettuce production under shelter need to address two problems. Firstly, although this production system is technically compatible with the easy introduction of solarisation, it greatly increases pathogenic risk compared with situations where the same lettuce is cropped in sequence with other crops (Hao et al., 2003). In the long term this would render the solarisation process ineffective because of the possible development of resistant pathogens. Secondly, the management of a tight sequence of lettuce cycles under difficult conditions at either end of the production calendar raises other questions. The shorter inter-crop periods require tighter technical management coupled with improved equipment. In particular, 
the soil needs to be tilled and the $n+1$ cycle planted on well dried soil to avoid compaction, which is detrimental to rooting and lettuce quality (de Tourdonnet et al., 2001). The irrigation of cycle $\mathrm{n}$ therefore needs to be finely controlled in such a manner as to reach these optimal moisture conditions at the start of cycle $n+1$ without compromising the growth and quality of the lettuce in cycle $\mathrm{n}$. In addition, the time allocated to harvesting a cycle is very short (1 week) with little room for manoeuvre: any shift in the maturity date caused by climatic factors or a shortage of labour and the entire crop sequence is threatened, possibly preventing execution of the 3 cycles scheduled. From a climatic standpoint, the temperatures reached at the two extreme ends of the calendar may be very high. Hence, the main risk in September is that the plants root poorly and in May that tip burn occurs (Thicoïpe, 1997). These risks can be reduced by selecting the appropriate variety: e.g. scarole is more susceptible than cos lettuce to changes in climate, and batavia is more heat-resistant (Thicoïpe, 1997). In such cases high, wellventilated shelters should be preferred (multispan plastic greenhouses rather than tunnels), or open-field cropping. As potential evapotranspiration increases greatly in the spring, care should be taken to ensure that irrigation parallels climaterelated needs to avoid the appearance of leaf necrosis, which renders the product impossible to sell. Climate control methods must therefore be developed to reduce quality defects, though it should be considered that little control can be exerted on the climate under plastic shelters. Indeed, although many climate control models are available (Challa et al., 1988), they generally concern heated, soil-less glasshouses, and more rarely tunnels where the climate can be controlled solely by ventilation, spraying and irrigation, with considerable lag times because of soil moisture. In conclusion, most farmers found technical solutions to stagger production cycles and use solarisation, and we now analyse what kind of leeway was involved at the farm level in each case and what kind of difficulties emerged.

\subsection{Farmers use the different types of leeway available at the farm level to introduce technical innovations}

\subsubsection{Staggering of harvest dates}

The previous analysis showed that farms adopt harvest staggering methods relatively independently of whether they are Type I, II or III (see Tab. III). Despite this structural orientation, each one therefore has its own leeway available to improve its cropping systems. The weight of two factors may here be highlighted: the surface area available under shelter (and, to a lesser degree, in open fields), and farm labourers' characteristics and the work allocated to these labourers.

When they possess substantial areas under shelter (more than 2.5 ha - 4 farms) the farms - all "specialised" Type II produce lettuce over 8 months and are obliged to deliver daily to optimise labour consisting mainly of unlimited-term salaried workers (between 5 and 13 people in addition to 1 or 2 family members). This prolongation over 8 months does not generally require recourse to open-field lettuce production. It normally uses either two lettuce cycle plots with plantation staggered between October and the end of May on large sheltered areas ( 8 ha for $\mathrm{C}_{13}$ ) or combinations of plots with 2 and 3 lettuce cycles
$\left(\mathrm{A}_{4}, \mathrm{C}_{9}\right)$. Specialisation in lettuce production is compatible with solarisation every year, but this is not always practised.

When sheltered areas are small (less than 1 ha - 12 farms), the farms - which are generally "mixed" Type I - deliver once a week and rarely seek to produce over 8 months. Orchards or vines often take priority over market garden crops. Labourers are employed in a supplementary and continuous manner on different productions: on lettuce from November to March, on potato in April, on peach in April (thinning) and in the summer (harvest) and on vine in the autumn. Sequences under tunnels are very varied: after lettuce, market gardeners install either a summer crop or a spring crop and green manure or solarisation, or even green manure alone or solarisation. The only farms producing lettuce over 8 months despite small sheltered areas $\left(A_{1}\right.$ and $\mathrm{A}_{9}$ ) both deliver to firm $\mathrm{A}$ and open field is used to start lettuce deliveries as early as possible. However, their small sheltered areas prevent them from producing continuously over 8 months.

Of those with moderately large areas under shelter (between 1 and 2.5 ha -17 farms) most (9 farms) were producing over 5 months. These were Type III "glasshousers" or Type II "lettuce specialists" but labour in both is devoted to tomato in summer either on the same plots as lettuce (Type II) or on different plots (glasshouse in Type III). The only farms producing lettuce over 8 months were: four "mixed" Type I farms delivering to firm A and calling on an employers' group for lettuce harvesting $\left(\mathrm{A}_{2}, \mathrm{~A}_{12}, \mathrm{~A}_{13}\right.$ and $\left.\mathrm{A}_{16}\right)$; and one "specialised" Type II farm $\left(B_{2}\right)$ using its 40 ha of open-field lettuce to stagger production by early deliveries in September and by recruiting seasonal labour on a day-to-day basis to match the ups and downs of open-field cropping. The only farms in the survey producing lettuce over 3 months ( 3 farms) possessed moderately large areas under shelter but very large orchards that are highly labour-intensive in the spring and summer.

Two farms behaved very differently from the others, as shown in Table III. The rationale for this was revealed by the analysis. Although farm $\mathrm{A}_{1}$ was producing over 8 months, its production was irregular because of the small area devoted to lettuce (1.5 ha). Farm $\mathrm{B}_{7}$ was harvesting daily for 3 months because lettuce here is a secondary crop and is used to occupy labour when no work is needed on other crops.

\subsubsection{Introducing solarisation}

By occupying all shelters with summer crops, seven farms were unable to use solarisation (S0) (Tab. IV). Those that devoted some of their shelters to lettuce alone (S1) were in principle able to use solarisation, but this was not the case at the time of the survey. Likewise, although nearly two-thirds of the farms (20 out of 33) followed model S3, which corresponds to a specialisation in lettuce cropping using all the shelters (possibly followed by a spring crop), only half were using solarisation (sometimes one year out of two), whereas the avoidance of summer crops could leave space for "intensive" solarisation every year (e.g. $\left.A_{12}\right)$, or for the use of green manure in alternate years $\left(A_{2}\right)(T a b . I)$. As a possible method of switching from $\mathrm{S} 1$ to $\mathrm{S} 3$, a few farms were using solarisation one year out of two (S2), enabling them to maintain a summer crop in rotation for half the area. 


\subsubsection{Two main strategies to combine the two technical innovations}

The first strategy to stagger production over more than three months and reduce chemical treatments of the soil by solarisation (H2S3, Tab. IV) consists of increasing sheltered surface area, specialising these shelters to produce lettuce and hiring permanent staff. This strategy involves some "level 2" leeway (avoidance of summer crops) but above all, considerable "level 3" leeway because the investment required (shelters and labour) substantially modifies the production resources of the farm. Solarisation is possible but is not widespread.

Farmers using the second strategy (H1S3) do not require any such investment. Here they opt to increase the number of cycles without increasing sheltered surface area, (i) by using two cycles in the open field (when such fields exist), and thereby modifying mainly the crop sequence ("level 1" leeway); (ii) and/or calling on seasonal labour in the early summer to replace that committed to other crops, e.g. orchards and vines in mixed farms ("level 2" leeway). The systematic introduction of solarisation in these systems would increase the workload, doubtless temporarily, when plastic mulch is installed.

These results show that in conventional, highly mixed farms that produce lettuce over 3 months, any increase in the number of cycles under shelter and the use of solarisation often causes substantial changes in the balance between the species within the farm. In such cases the summer crop used to be the priority, with lettuce being used simply to make full use of the tunnels. However, with the introduction of solarisation in particular, the summer crop is reduced or even avoided, and this phenomenon is reinforced by the fact that such crops have become less profitable over the last few years.

This trend may be perceived today by the emergence of two contrasting production and marketing models: (1) very intensive farms that are growing in size are specialised in lettuce production over 8 months and can employ solarisation without difficulty. These farms commercialise large volumes by means of a long marketing chain (superstores and supermarkets, and processors of ready-to-eat vegetables) either directly or via marketing firms with which they work in close partnership (Navarrete et al., 2003; see also Sect. 3.3); and (2) far more mixed farms that cannot produce solely lettuce over a long period or use solarisation on a regular basis. Most of them turn to more local, seasonal outlets (periurban and direct sales), possibly converting to organic agriculture, and as a consequence, further increasing their level of diversification.

By restricting our analysis to these two techniques and to their effects on the management of lettuce crop sequences and farm resources, we were unable to categorise the effects of workload plans and specifications on the crop management sequence, unlike other authors in their consideration of arable crops (Vaucelle and Le Bail, 2004; Wünsch, 2004). However, more generally, our results confirm previous works on very different cropping systems, as regards the great diversity in the leeway available from one farm to the next (Joannon et al., 2005). Nevertheless, how to manage when no individual leeway is available, or when its use affects the basic structure of the farm? We now analyse the co-ordinations between marketing firms and their suppliers to understand if new leeway may be available at the supply basin level.

\subsection{Orchestrating improved between-farm coordination provides new types of leeway in the supply basin area}

As already seen, solarisation would be possible in a large proportion of the farms without too many structural modifications. However, at the time the survey was conducted, the superstores and the processors of ready-to-eat vegetables were not imposing such a move, and neither were the marketing firms. By contrast, it was also seen that the staggering of harvests, as employed by most farms, used leeway that affects the production resources of the farm. Some marketing firms therefore employ procedures that lend farms a certain flexibility. These may be divided into two strategies: (1) by providing organisational support and a contract-based guarantee they incite farmers to modify three key variables: surface areas under shelter, planting dates and seasonal labour. This was the choice made by firm A. (2) By specialising a few farms for lettuce production at the extreme ends of the production calendar without weighing on the leeway available to other farms. This was the choice made by firm $B$ and, to a lesser extent, by firm $C$.

Hence, firm A uses subsidised loans to incite market gardeners to build shelters that can facilitate lettuce cropping early and late in the season, and to improve product quality. By providing the plants, it increases the chances of success in systems based on 3 lettuce cycles per year. In this way, it obliges the market gardeners to comply with the agreed timetable because the plants delivered cannot be stored for more than a few days prior to planting. Also, if plant maturity is shifted by climatic factors, it organises plant exchanges between producers. An employers' group managed by A enables market gardeners to resolve peak workloads at little extra cost without having to find and train temporary staff. Finally, the contracts agreed between producers and the firm, in particular for the two extreme ends of the season, guarantee that production will be correctly remunerated even if quality levels fall. With this organisation, most of the farms supplying firm A were able to develop their cropping systems. This demonstrates why some farms, who according to the analysis in Section 3.2 are less flexible (small areas under shelter, not specialised in lettuce production), increased from 2 to 3 lettuce cycles under shelter $\left(A_{1}, A_{2}, A_{5}, A_{6}\right.$ and $\left.A_{12}\right)$, or from 1 to 2 cycles in open fields $\left(A_{15}\right.$ and $\left.A_{17}\right)$. Others that were already using 3 cycles under shelter $\left(A_{4}\right.$ and $\left.A_{16}\right)$ responded to the request of firm $\mathrm{A}$ by staggering plantings, starting earlier at the beginning of the season and ending later, thereby prolonging the total harvesting period. Firm A considered it necessary to implement these procedures because it itself is subject to considerable pressure at the start and end of the production period from firms that deal in ready-to-eat vegetables (Tordjman et al., 2005).

Firm B made far fewer moves to incite producers to stagger their harvest and far fewer changes were made. The only farms supplying firm B over 8 months were the two managed by the firm itself, and this explains the increase from 2 to 3 cycles under shelter in $\mathrm{B}_{9}$ and from 1 to 2 cycles in the open field in $B_{2}$. These are also the only two farms in the sample specialised in lettuce (Type II) and alone account for $40 \%$ of the supplies delivered to firm $\mathrm{B}$. In view of the few guarantees provided by the firm, the other market gardeners supplying firm B considered it too risky to increase their number of cycles. 
Firm $\mathrm{C}$ also intervenes little in its supply basin with regard to farmer leeway. Specialised farms possess very large sheltered areas managed by a considerable workforce of permanent staff $\left(\mathrm{C}_{6}\right.$ possesses 6 ha under shelter and 9 unlimited-contract farm labourers, and $\mathrm{C}_{13}$ has 8 ha under shelter and 13 unlimitedcontract farm labourers). The mixed farms use 1 or 2 cycles. That little pressure is applied here to make changes is doubtless due to the fact that the firm itself owns a plant used to process ready-to-eat vegetables and therefore is less demanding in terms of production dates than firm $\mathrm{A}$, which is bound by contract to external processors.

More generally, it can now be seen why the farms that produce over 8 months are not all "specialised lettuce producers" with large surface areas under tunnels, but also include more mixed farms : in such farms, strong encouragement from marketing firms has allowed cropping systems to evolve, whereas the results in Sections 3.1 and 3.2 led us to conclude that they were not well adapted to the marketing constraints. In fact, they do participate in the collective management of the supply basin which itself is directed toward long marketing chains, since their greater flexibility allows them to meet peaks in customer needs. These results confirm that quality management has to be studied at the local crop supply system level including field, farm and collecting system, where new leeway could be found to reach market objectives, as has been shown for the cereal and sugar industries (Higgins, 2003; Le Bail, 2004, 2005).

\section{CONCLUSION}

Our aim was to place technical innovations within a global analysis of farming systems and an evaluation of the relations between farms and marketing firms. We demonstrated that farmers use various technical solutions to stagger harvests and use solarisation, depending on their own leeway at the farm level or collective leeway at the supply basin level. In the relation between farm system functioning (strategies and resource organisation) and the capacity of these farms to integrate the two technical innovations, the area available under shelter and farm labourers' characteristics appeared to be key variables. However, we also showed that marketing firms can promote this evolution by developing closer economical and technical relations with their suppliers. They could participate in the preservation of a diversity of technical systems and farms, which is crucial in a logic of sustainable development: for example, mixed farms are useful in that they reduce waste seeping into the water table, they maintain biological diversity (species cropped and biological agents), they employ permanent labour and continue to use the land. The study reported here can serve two purposes. Firstly, it may contribute to improving organisational effectiveness by proposing a method of analysis that is sensitive to the diversity of the resources available and operator strategies. Secondly, it can also be used to identify or predict the emergence of organisational and technical malfunctions. Finally, it broadens the use of farmer decision models mainly developed in generally simpler major cropping systems (Aubry et al., 1998; Rossing et al., 1997; Vaucelle and Le Bail, 2004) to the case of market garden systems that are fairly diverse and complex in their technical management.

\section{REFERENCES}

Agreste (2001) Recensement agricole fruits et légumes de Pyrénées-Orientales, Octobre 2001.

Anon. (1993) Fiche solarisation, Chambre d'agriculture 66, SICA-Centrex ; CIVAM-Bio.

Aubry C., Papy F., Capillon A. (1998) Modelling decision-making processes for annual crop management, Agric. Syst. 56, 45-65.

Capillon A. (1993) Typologie des exploitations agricoles, Contribution à l'étude régionale des problèmes techniques, Thesis INA P-G, Paris, $301 \mathrm{p}$.

Capillon A., Valceschini E. (1998) La coordination entre exploitations agricoles et entreprises agro-alimentaires, Un exemple dans le secteur des légumes transformés, Étud. Rech. Syst. Agraires Dév. 31, 259-275.

Challa H., Bot G., Nederhoff E., Van De Braak N. (1988) Greenhouse climate control in the nineties, Acta Hort. 230, 459-470.

Dogliotti S., Rossing W.A.H., van Ittersum M.K. (2004) Systematic design and evaluation of crop rotations enhancing soil conservation, soil fertility and farm income: a case study for vegetable farms in South Uruguay, Agr. Syst. 80, 277-302.

Goisque M.J. (1994) Calendriers de plantation, Salade haute définition, Cahier hors-série Fruits et Légumes, Echo des MIN, pp. 44-47.

Hao J.J., Subbarao K.V., Koike S.T. (2003) Effect of broccoli rotation on lettuce drop caused by Sclerotinia minor and on the population density of sclerotia in soil, Plant Dis. 87, 159-166.

Higgins A.J., Muchow R.C. (2003) Assessing the potential benefits of alternative cane supply arrangements in the Australian sugar industry, Agr. Syst. 76, 623-638.

Joannon A., Martin P., Papy F., Souchère V. (2005) Planning work constraints within farms to reduce runoff at catchment level, Agr. Ecosyst. Environ. 111, 13-20.

Jones E.E., Mead A., Whipps J.M. (2004) Effect of inoculum type and timing of application of Coniothyrium minitans on Sclerotinia sclerotiorum: control of sclerotinia disease in glasshouse lettuce, Plant Pathol. 53, 611.

Katan J. (1981) Solar heating (solarisation) of soil for control of soil-born pests, Annu. Rev. Phytopathol. 19, 211-236.

Landais E. (1998) Modelling farm diversity: new approaches to typology building in France, Agr. Syst. 58, 505-527.

Latham L.J., Jones R.A.C. (2004) Deploying partially resistant genotypes and plastic mulch on the soil surface to suppress spread of lettuce big-vein disease in lettuce, Aust. J. Agric. Res. 55, 131-138.

Le Bail M. (2004) A design for a local crop supply system as a quality management territory, in: Jacobsen S.E., Jensen C.R., Porter J.R. (Eds.), European agriculture in a global context, European Society of Agronomy, Copenhaguen, Denmark, pp. 527-528.

Le Bail M. (2005) Le bassin d'approvisionnement : territoire de la gestion agronomique de la qualité des productions végétales, in: Prevost $\mathrm{P}$. (Ed.), Agronomes et territoires : Deuxième édition des entretiens du Pradel, L'Harmattan, Paris, France, pp. 213-228.

Le Bohec J., Giraud M. (1999) Désinfecter les sols autrement, Ctifl, Paris, France.

Maxime F., Mollet J.M., Papy F. (1995) Aide au raisonnement de l'assolement en grande culture, Cah. Agric. 4, 351-362.

Minuto A., Gilardi G., Gullino M.L., Garibaldi A. (2000) Combination of soil solarisation and dazomet against soilborne pathogens of glasshouse-grown basil, tomato and lettuce, Acta Hort. 532, 165170 . 
Navarrete M., Tordjman S., Rouby A. (2003) La planification des plantations par les structures de première mise en marché dans la filière fruits et légumes, Comparaison des cas de la salade et de la pêche dans le Sud-Est de la France, Fruits 58, 261-274.

Nico A.I., Rollan M.C., Monaco C.I., Dal Bello G.M. (2003) Organic amendment effects on survival and incidence of lettuce drop caused by Sclerotinia minor, Biol. Agric. Hort. 21, 103-114.

Oniflhor, Ctifl and Fnpl (2000) Observatoire des exploitations légumières, Paris.

Papy F. (2001) Interdépendance des systèmes de culture dans l'exploitation agricole, in: Malézieux E., Trébuil G., Jaeger G. (Eds.), Modélisation des agro-écosystèmes et aide à la décision, INRA, Collection Repères, Paris, France, pp. 51-74.

Rossing W.A.H., Meynard J.M., Van Ittersum M.K. (1997) Model-based explorations to support development of sustainable farming systems: case studies from France and the Netherlands, Eur. J. Agron. $7,271-283$.

Sebillotte M., Soler L.G. (1988) Le concept de modèle général et la compréhension du comportement de l'agriculteur, C.R. Acad. Agric. $74,59-70$
Stapleton J.J. (2000) Soil solarisation in various agricultural production systems, Crop Prot. 1, 837-841.

Thicoïpe J.P. (1997) Laitues, Ctifl, Paris.

Tordjman S., Navarrete M., Papy F. (2005) Les formes de coordination technique entre des structures de première mise et leurs apporteurs, Cah. Agric. 14, 479-484.

de Tourdonnet S., Meynard J.M., Lafolie F., Roger-Estrade J., Lagier J., Sebillotte M. (2001) Non-uniformity of environmental conditions in greenhouse lettuce production increases the risk of $\mathrm{N}$ pollution and lower product quality, Agronomie 21, 297-309.

Vaucelle A., Le Bail M. (2004) Diversité des engagements contractuels et fonctionnements des exploitations agricoles en Beauce, in: SFER (Ed.), Les systèmes de production agricole : performances, évolution, perspectives, Lille, France.

Villeneuve F. (1999) Légumes de plein champ, Protection phytosanitaire respectueuse de l'environnement, Ctifl, Paris.

Wünsch J.A. (2004) Intégration des contraintes du marché dans la conduite des cultures : effet de la différenciation des produits sur la conduite de la culture de pomme de terre de conservation dans les exploitations agricoles de Picardie, Thesis INA P-G, Paris. 